\title{
Appearance of the common paper nautilus Argonauta argo related to the increase of the sea surface temperature in the north-eastern Atlantic
}

\author{
A. Guerra*, A.F. González and F. Rocha \\ ECOBIOMAR, Instituto de Investigaciones Marinas (CSIC), Eduardo Cabello 6, 36208 Vigo, Spain. \\ *Corresponding author, e-mail: brcl@iim.csic.es
}

\begin{abstract}
The relationship between the increase of the sea surface temperature observed off the Galician coast and the appearance of a tropical poikilotherm species Argonauta argo in these coasts is discussed. This is the first record of Argonauta argo in the north-west Iberian Peninsula. A female of this species was captured alive near the surface at dusk on 22 December 2000 in the Ria de Aldán $\left(42^{\circ} 15^{\prime} \mathrm{N}-08^{\circ} 48^{\prime} \mathrm{W}\right)$. The specimen, a mature female of $70 \mathrm{~mm}$ mantle length and $96 \mathrm{~mm}$ shell diameter, died 36 hours after introduction in the tank.
\end{abstract}

\section{INTRODUCTION}

The common paper nautilus, Argonauta argo L., 1758, is an octopod with a very acute sexual dimorphism. Adult females are between 10 and 15 times larger than males. The female secretes a thin, laterally compressed calcareous white and large shell (up to $25 \mathrm{~cm}$ ) with one chamber. This shell has a flat narrow black or brown keel fringed by two rows of smooth tubercles, which are more than 50 in large shells. The keel rarely exceeds $6 \%$ of the shell diameter. The lateral sides of the shell have numerous radial ribs closely arranged and often splitting in two. The dorsal arms are the largest in females and bear a wide lobe or membrane resembling a sail. The shell is formed by secretions of these arms. Males are tiny and dwarf, and the third left arm is hectocotyilized. The hectocotylus has a long slender penis and about 65 suckers arranged in two rows. This arm is placed in the mantle cavity of the female for a considerable interval. Eggs are very small (0.6$0.8 \mathrm{~mm})$. The female broods the eggs in the shell until hatching of the larvae (Naef, 1923; Nesis, 1987; Guerra, 1992).

Argonauta argo is an epipelagic octopod. It has been recorded throughout the whole Mediteranean Sea (Mangold \& Boletzky, 1988). In the western Pacific this species was cited from southern Hokkaido in Japan to New Zealand (Okutani et al., 1987; Nesis, 1987). However, A. argo was recorded from California to Peru in the eastern side of the Pacific ocean (Nesis, 1987). In the western Atlantic, it was found from Cape Cod to waters off Venezuela (Nesis, 1987; Hochberg et al., 1992), whereas this species is distributed from the Portuguese coast to South Africa in the eastern Atlantic (Nesis, 1987). To date, A. argo has been recorded in the Azores and Madeira Archipelagos (Gonçalves, 1991; Gonçalves \& Martins, 1992). The northern boundary of this species is situated in Portuguese waters (Girard, 1889), up to Peniche and Berlengas Islands $\left(39^{\circ} 28^{\prime} \mathrm{N}-09^{\circ} 35^{\prime} \mathrm{W}\right)$. Argonauta argo has been observed alive many times. However, aquarium studies of the living females are very scarce (Boletzky, 1983). This paper deals about the first record of $A$. argo in the north-west Iberian Peninsula.

\section{RESULTS AND DISGUSSION}

A female of this species was observed alive near the surface at dusk on 22 December 2000 in the Ria de Aldán $\left(42^{\circ} 15^{\prime} \mathrm{N}-08^{\circ} 48^{\prime} \mathrm{W}\right)$. This animal was transported by the current flow. The observer (a professional fisherman) introduced the animal, which apparently was in good condition, in a creel and it remained there for 12 hours. Once the animal was released from the creel, it maintained its buoyancy but slightly listed to one side. Then, it was transported to the laboratory and placed in a 200-l tank with an open seawater system at $18^{\circ} \mathrm{C}$. Two strings of eggs were fixed within the narrower part of the shell opening, near the horn. The egg mass contained 636 ovoid eggs. Mean length was $1.098 \mathrm{~mm}$ (standard deviation $0.057 ; \mathrm{N}=40$ ) and mean width was $0.765 \mathrm{~mm}$ (standard deviation $0.024 ; \mathrm{N}=40$ ). The animal was photographed in the wild and in the tank (Figure 1). The specimen, a mature female of $70 \mathrm{~mm}$ mantle length and $96 \mathrm{~mm}$ shell diameter, died 36 hours after introduction in the tank.

In the tank, the animal maintained its buoyancy and the arms were held within the shell in the inverted position typical of female Argonauta. The animal swam around the tank expelling water through its funnel. It had difficulties to maintain an upright position. Sometimes, it remained stationary fixed to the tank walls by the suckers. During the first hours after introduction, the animal showed no interest in food and then it was hand fed with small pieces of Ammodytes and squid. The specimen ingested a minor part of the food provided. After 14 hours the animal did not ingest further food. Twenty-two hours after introduction, the animal was found outside its brood shell to which it remained attached only with the dorsal arms. Within the next two hours, it became moribund. Generally, the behaviour pattern was similar to the observed by Boletzky (1983). However, although our animal was apparently undamaged, it did not survive for an extended period probably due to the stress suffered by the animal within the creel and also due to the rough sea conditions during that night. 


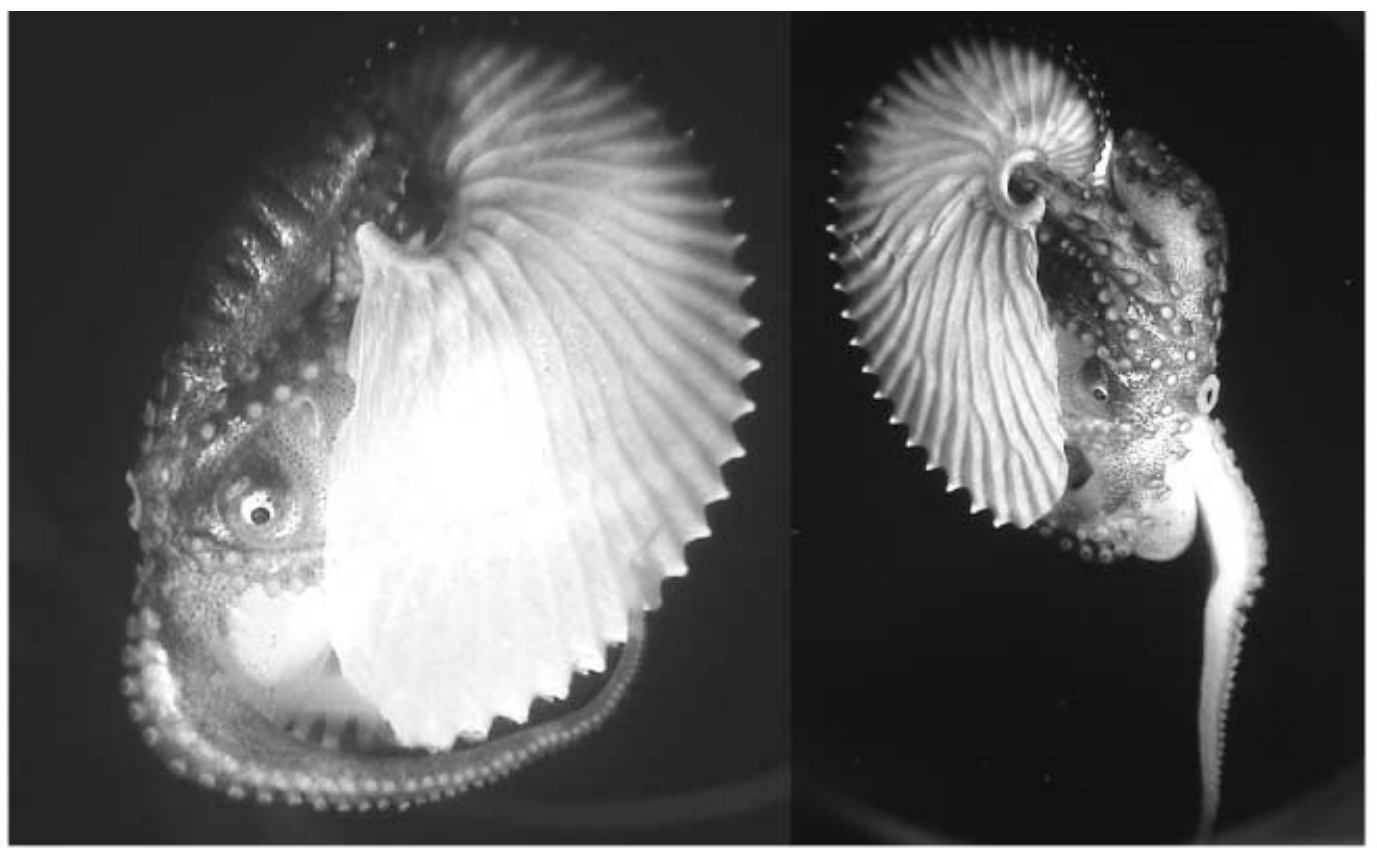

Figure 1. Mature female of Argonauta argo caught alive in the Ría of Aldán in December 2000. Photographs by José Luis González/Marevisión.

The northern record of Argonauta argo in the northeastern Atlantic was situated in waters off Lisbon $\left(39^{\circ} 28^{\prime} \mathrm{N}-09^{\circ} 35^{\prime} \mathrm{W}\right)$. However, Pérez-Gándaras (1980) and Guerra (1992) suggested that $A$. argo could be transported occasionally towards the north and could reach the north-western Spanish waters. In this paper we prove for the first time the appearance of this species at latitudes up to $42^{\circ} \mathrm{N}$. Therefore, the record of this living female extends the northern limit of the distribution of this species by about 180 nautical miles.

Argonauta has been observed in an unusual attitude, several females forming a string by holding on to each other (Voss \& Williamson, 1971). To date, this behaviour has not been reported for Argonauta argo but, as we observed in the laboratory as well as suggested by Young (1960), the specimens tend to hold on to solid substrates on occasions. This behaviour led Boletzky (1983) to indicate that the specimen he found in the Banyuls harbour could be transported by a sailing boat that had cruised off-shore and entered in the harbour without strong winds or currents being involved. However, in our case, Aldán has no proper harbour or any sailing or commercial port. Furthermore, when the animal was captured, strong winds and currents from the south-west prevailed in Galician waters. This suggests that the animal was transported from southern latitudes.

This finding coincides with the sudden appearance of other subtropical and tropical species in Galician waters. Thus, in September 1998 the first mass stranding of shortfinned pilot whales (Globicephala macrorhynchus Gray, 1846) in the north-eastern Atlantic was recorded (González et al., 2000). This species was rarely seen north of Madeira in the eastern Atlantic. Furthermore, we recently found one adult male of Alloteuthis africana Adam, 1950 measuring $223 \mathrm{~mm}$ total length fished alive off Gijón $\left(43^{\circ} 52.54^{\prime} \mathrm{N}-05^{\circ} 18.74^{\prime} \mathrm{W}\right)$ in December 2000. The northern limit of this species was situated off the western

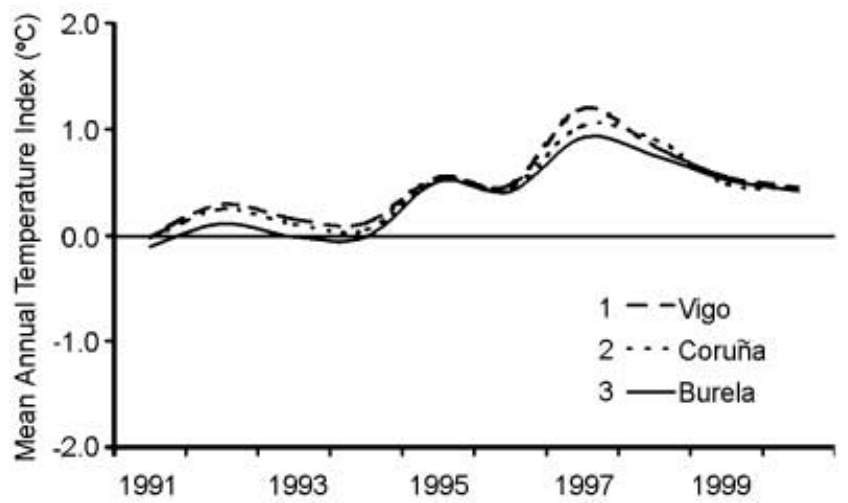

Figure 2. Mean annual surface temperature index from 1991 to 2000 showing the sea temperature anomaly measures taken off Vigo (1), Coruña (2), and Burela (3).

Sahara (Adam, 1951). Additionally, stranding of juveniles of the tropical loggerhead sea turtle (Caretta caretta L., 1758), which are rehabilitated by our research group, increased notably during autumn and winter 2000 and 2001. We have to add to these records, the capture of an adult male king fish (Caranx hippos L., 1766) captured alive in the Ría de Vigo in October 1997. The geographical distribution of this species comprised tropical and subtropical Atlantic waters up to southern Portuguese waters, being rare in the Mediterranean Sea (Bauchot \& Pras, 1987).

From a faunistic point of view, the Galician waters represent a crossroad of boreal and subtropical marine faunas. For instance, the boreal octopod Bathypolypus arcticus has Galicia as its southern boundary of its geographical distribution, whilst the Mediterranean and Lusitanian octopod Bathypolypus sponsalis has Galicia as its northern boundary (Pérez-Gándaras \& Guerra, 1978). Lately, records of subtropical and tropical species are 


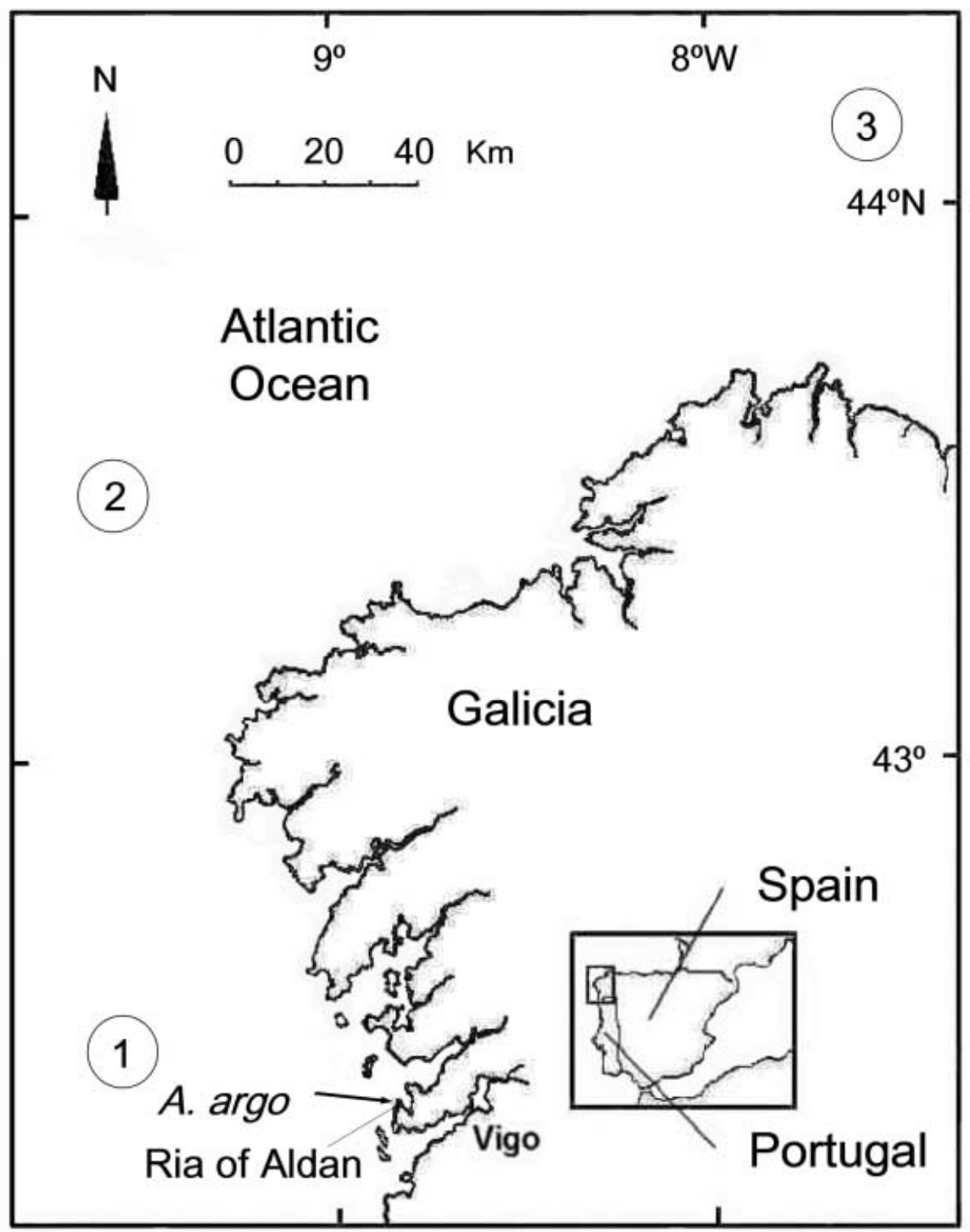

Figure 3. Map illustrating the locality where Argonauta argo was collected and the localization of the sampling sites where the sea surface temperature were registered (See Figure 2).

increasingly frequent on our coasts. The occurrence of Argonauta argo and the other above mentioned species in Galician waters could be explained by an ingress of warm water masses that flow northwards.

The mean annual sea surface temperature index from 1991 to 2000 (Figure 2) showed the sea temperature anomaly measures taken off Vigo (1), Coruña (2) and Burela (3) in Galician waters (Figure 3). These data were obtained from ship surveys and buoys, and bias-corrected by satellite data (IGOSS, National Meteorological Centre, Monthly Sea Surface Temperature Anomaly Web page). During this period, a clear increase of the sea surface temperature was observed off the Galician coast. Especially, since 1995, the mean annual temperature index off Galicia reflects an increase of $1.2^{\circ} \mathrm{C}$ (Figure 2). This increase of temperature is probably due to the presence of a warm $\left(15.0-15.5^{\circ} \mathrm{C}\right)$, salty surface current flowing poleward along the Iberian Peninsula (Frouin et al., 1990; Pingree \& Le Cann, 1990; Neves et al., 1995). This current flows over $1500 \mathrm{~km}$ along the upper continental slope-shelf break zone off western Portugal, north- west and northern Spain, and south-west France. This water mass is relatively wide $(25-40 \mathrm{~km})$, extending from the surface to $200 \mathrm{~m}$ depth and it is characterized by velocities ranging from 0.2 to $0.3 \mathrm{~m} \mathrm{~s}^{-1}$ (Frouin et al., 1990). Prevailing south-east winds during the autumn and beginning of winter could transport associated animals poleward towards the coast and would explain the appearance of these species, especially poikilotherm ones, as Argonauta argo, in this area. The current interest in climate change sets our data as evidence to support species change associated to increase in sea temperature.

We thank Fernando González Barreiro for providing the animal. We also thank José Luis González and Javier Irisarri for providing photos of the animal in the wild and Maria T. Fernández for her technical assistance.

\section{REFERENCES}

Adam, W., 1951. Les céphalopodes de l'Institut Français d’Afrique Noire. Bulletin de l'Institut Français d'Afrique Noire, 13, 771-787. 
Bauchot, M.L. \& Pras, A., ed. 1987. Guía de los peces de mar de España y Europa. Barcelona: Omega.

Boletzky, S. von, 1983. Laboratory observations on a female Argonauta argo (Mollusca: Cephalopoda). Rapports et Procèsverbaux des Réunions. Commission Internationale pour l'Exploration Scientifique de la Mer Méditerranée, 25, 289-290.

Frouin, R., Fiúza, A.F.G., Ambar, I. \& Boyd, T.J., 1990. Observations of a poleward surface current off the coasts of Portugal and Spain during winter. Fournal of Geophysical Research, 95, 679-691.

Girard, A., 1889. Nota sobre os Cephalópods de Portugal. Fournal de Sciences Mathematicas, Physicas e Naturaes, 3, 200-205.

Gonçalves, J.M., 1991. The Octopoda (Mollusca: Cephalopoda) of the Azores. Arquipélago, 9, 75-81.

Gonçalves, J.M. \& Martins, H.R., 1992. Additions to the Octopoda (Mollusca: Cephalopoda) fauna of Madeira. Bocagiana, 157, 1-11.

González, A.F., López, A. \& Valeiras, X., 2000. First recorded mass stranding of short-finned pilot whales (Globicephala macrorhynchus Gray, 1846) in the northeastern Atlantic. Marine Mammals Science, 16, 640-646.

Guerra, A., 1992. Mollusca: Cephalopoda. In Fauna Ibérica, vol. 1 (ed. M.A. Ramos et al.), pp. 1-327. Madrid, Spain: Museo Nacional de Giencias Naturales/CSIC.

Hochberg, F.G., Nixon, M. \& Toll, R.B., 1992. Order Octopoda Leach, 1818. In "Larval" and juvenile cephalopods: a manual for their identifications (ed. M.J. Sweeney et al.). Smithsonian Contributions to Zoology, 513, 213-279.

Integrated Global Ocean Services System (IGOSS), National Meteorological Centre (NMC), Monthly Sea Surface Temperature Anomaly Web page: http://ingrid.ldgo.columbia.edu/ SOURCES/.IGOSS/.nmc/.monthly/.ssta/
Mangold, K.M. \& Boletzky, S. von, 1988. Mediterranean cephalopod fauna. In Paleontology and neontology of cephalopods. Vol. 12. The Mollusca (ed. M.R. Clarke and E.R. Trueman), pp. 315-330. London: Academic Press.

Naef, A., 1923. Die Cephalopoden. Fauna e Flora del Golfo di Napoli, 35, 313-863.

Nesis, K.N., 1987. Cephalopods of the world. Neptune City, NJ: T.F.H. Publications.

Nevez, R., Santos, A. dos, Coelho, H. \& Rosa, T.L., 1995. Development of a 3-D pronostic equation model. Ocean Margin Exchange OMEX. Second Annual Report. Part B, pp. B69B83.

Okutani, T., Tagawa, M. \& Horikawa, H., 1987. Cephalopods from continental shelf and slope around Japan. Tokyo: Japan Fisheries Conservation Association.

Pérez-Gándaras, G., 1980. Cefalópodos del mar de Galicia. Tesis de Licenciatura, Universidad Complutense de Madrid, Spain.

Pérez-Gándaras, G. \& Guerra, A., 1978. Estudio sobre algunas especies del género Bathypolypus (Cephalopoda, Octopoda) halladas en las costas de Galicia. Investigación Pesquera. Barcelona, 42, 189-211.

Pingree, R.D. \& Le Cann, B., 1990. Structure, strength and seasonality of the slope currents in the Bay of Biscay region. Fournal of the Marine Biological Association of the United Kingdom, 70, 857-885.

Voss, G.L. \& Williamson, G., 1971. Cephalopods of Hong Kong. Hong Kong Government Press.

Young, J.Z., 1960. Observations on Argonauta and especially its methods of feeding. Proceedings of the Royal Society of London, 133, $471-479$.

Submitted 20 March 2001. Accepted 10 July 2002. 